\title{
Discrimination ability of Santa Inês and crossbred Santa Inês $\times$ Dorper lamb heavy carcasses by the Brazilian and European classification systems
}

\author{
Alyne Cristina Sodré Lima', Marco Antonio Paula de Sousa ${ }^{1}$, Jonas Carneiro Araújo², Manuella \\ Paula de Mesquita Nunes ${ }^{2}$, Eziquiel de Morais ${ }^{3}$, Stefano Juliano Tavares de Andrade ${ }^{1}$, Luciara \\ Celi da Silva Chaves ${ }^{2}$, André Guimarães Maciel e Silva ${ }^{1 *}$
}

\footnotetext{
${ }^{1}$ Universidade Federal do Pará, Instituto de Medicina Veterinária, Programa de Pós-graduação em Ciência Animal, Castanhal, PA, Brazil.

${ }^{2}$ Universidade Federal Rural da Amazônia, Programa de Pós-graduação em Saúde e Produção Animal na Amazônia, Belém, PA, Brazil.

${ }^{3}$ Instituto Federal de Ciência e Tecnologia do Pará, Castanhal, PA, Brazil.
}

ABSTRACT - The ability of discriminating carcass characteristics of different fat cover scores of heavy carcasses, according to the European (EUS) and Brazilian (BRS) classification systems, was assessed. Fifty-six lambs, weighing between 26.25 and $46.15 \mathrm{~kg}$, of the Santa Inês and crossbred Santa Inês $\times$ Dorper genetic groups were evaluated. The level of adiposity was assessed through color photography of the carcasses after refrigeration according to the EUS and BRS. The carcasses were assigned to four groups by cluster analysis according to 25 variables, namely, cold carcass weight; muscle; bone; fat; and muscle:fat and fat:bone ratios of the carcass and cuts (hindquarter, shoulder, back); kidney, pelvic, and inguinal fat; and subcutaneous fat thickness. Of the four groups obtained by cluster analysis, the scores according to the different classification systems only statistically differed between groups 1 and 4. The BRS had a higher number of variables well correlated with the scores by assessors than the groups classified by the EUS. The BRS was better correlated with tissue composition. However, most variables were better correlated with backfat thickness than the score obtained through the classification systems. Better results were obtained regarding the prediction of carcass fat by the BRS using backfat thickness or cold carcass weight. The Brazilian lamb carcass classification system better predicts tissue composition and is the best method to discriminate intermediate-fat classes when associated with cold carcass weight.

Key Words: conformation, non-specialized breeds, tissue composition

\section{Introduction}

The evaluation of lamb carcasses in Brazil employs grading systems that include the fat score as a criterion of quality and price. To evaluate the grease status as a variable that interferes with carcass and meat quality, it influences the appearance, color, succulence, and acceptance of the product by the consumer (Pannier et al., 2014). Such systems assess the carcass fat content subjectively and can help predict its edible portion and fleshiness.

Received: September 29, 2016

Accepted: February 21, 2017

*Corresponding author: andregms@gmail.com

http://dx.doi.org/10.1590/S1806-92902017000600008

How to cite: Lima, A. C. S.; Sousa, M. A. P.; Araújo, J. C.; Nunes, M. P. M.; Morais, E.; Andrade, S. J. T.; Chaves, L. C. S. and Silva, A. G. M. 2017. Discrimination ability of Santa Inês and crossbred Santa Inês $\times$ Dorper lamb heavy carcasses by the Brazilian and European classification systems. Revista Brasileira de Zootecnia 46(6):527-536.

Copyright (C) 2017 Sociedade Brasileira de Zootecnia. This is an Open Access article distributed under the terms of the Creative Commons Attribution License (http://creativecommons.org/licenses/by/4.0/), which permits unrestricted use, distribution, and reproduction in any medium, provided the original work is properly cited.
Commonly in Brazil, the classification of ovine carcasses is carried out according to the standards established by the classification system of carcasses EUROP, European Union (EUS), which classifies the carcasses regarding cold carcass weight $(\mathrm{CCW})$ as heavy when $\mathrm{CCW} \geq 13 \mathrm{~kg}$ and grades them regarding conformation using photographic standards on a scale from 1 to 6 , ranging from poor to superior, respectively (European Union, 1994). However, the evaluation of carcasses using that score system leads to difficult distinctions, since the reference images are far apart from one another concerning the level of adiposity, which hinders evaluation using those photographic standards (Miguel et al., 2003).

Although Brazil has its own classification system (BRS), it is little known in lamb slaughterhouses in the country. The BRS classifies carcasses according to categories common to other systems, such as sex, maturity, and weight, grading them according to fat cover on a scale from 1 to 5 , corresponding to lean to very fat, respectively (Brasil, 1990). This system was mainly developed to meet the requirements of animals reared in the tropics, which, due to adaptive evolution and even food scarcity, excessive 
amounts of fat stored internally, may compromise the homogenicity traits in external fat cover, therefore, adjustments are required to address the irregularity found in carcasses obtained in Brazil (Medeiros et al., 2011). Regardless of the system, methods based on scores are efficient for being quick and allowing the carcass to be evaluated in few seconds with no damage to it.

This study aimed to assess the discrimination ability of carcass characteristics and tissue composition of the different conformation scores according to the European lamb carcass classification system and the Brazilian lamb carcass classification system for heavy carcasses.

\section{Material and Methods}

Fifty-six lambs, weighing between 26.25 and $46.15 \mathrm{~kg}$ and having $C C W \geq 13 \mathrm{~kg}$, of the Santa Inês $(\mathrm{n}=26)$ and crossbred Santa Inês $\times$ Dorper $(n=30)$ genetic groups, were evaluated. No significant difference $(\mathrm{P}>0.05)$ was observed between the genetic groups evaluated for the variables analyzed in this study, which enabled the two groups to be assessed jointly. The carcasses were kept at $4^{\circ} \mathrm{C}$ for $24 \mathrm{~h}$ and then photographed for later classification by trained assessors.

After refrigeration, the $\mathrm{CCW}$, carcass weight, and pelvic, kidney, and inguinal fat weights were obtained (Table 1). The whole carcasses were photographed for classification, by three trained evaluators, according to the degree of fat cover established by the EUS (1: low, 2: slight, 3: average, 4: high, and 5: very high) (European Union, 1994) and by the BRS (1: lean, 2: slight fat, 3: average fat, 4: uniform fat, and 5: excessive fat) (Brasil, 1990).

The whole carcasses were split into symmetrical halfcarcasses, whose backfat thickness (BFT) was measured, in millimeters, between the 12 th and 13 th ribs. The halfcarcasses were then divided into cuts and separated into muscle, fat, and bone (Colomer-Rocher et al., 1984). The percentages of muscle, fat, and bone, as well as the muscle:fat and fat:bone ratios in the carcass and cuts were determined.

The statistical analysis included cluster analysis based on Pearson's dissimilarity and agglomeration method of complete linkage, Spearman's correlation analysis, and variance analysis, using the model:

$$
Y_{i j}=\mu+\alpha_{i}+\varepsilon_{i j} \text {, }
$$

in which $\mathrm{Y}_{\mathrm{ij}}=$ observation for tissue composition variables; $\mu=$ overall mean; $\alpha_{i}=$ fixed effect of groups (Cluster (4), EUS (4), or BRS (3)) i observed value in $\mathrm{Y}_{\mathrm{ij}}$; and $\varepsilon_{\mathrm{i}}=$ random errors $\left(\varepsilon_{\mathrm{ij}} \sim \mathrm{IN}(0, \sigma 2)\right)$, with Tukey's test at $5 \%$ significance level, adopted to compare to what extent each classificatory variable influences the response variable, and regression analysis, in which:

$$
\begin{gathered}
\text { linear: } y=\alpha+\beta_{1} x_{1}+\varepsilon \text { and } \\
\text { linear multiple: } y=\alpha+\beta_{1} x_{1}+\beta_{2} x_{2}+\varepsilon,
\end{gathered}
$$

in which $\mathrm{y}=$ observation for tissue composition variables; $\mathrm{x}_{1}=$ system of carcass classification, EUS or BRS; $\mathrm{x}_{2}=\mathrm{BFT}$ or $\mathrm{CCW} ; \alpha, \beta_{1}$, and $\beta_{2}=$ regression coefficients; $\varepsilon=$ random error $(\varepsilon \sim \operatorname{IN}(0, \sigma 2))$. The statistical procedures were carried out using the software SAS (Statistical Analysis System, version 9.2).

\section{Results}

The carcasses were grouped (Figure 1) into four clusters and a significant statistical effect was observed for the variables $\mathrm{CCW}$, carcass composition, and fat cover, except for inguinal fat (Table 2). Clusters 1 and 4 differed regarding all variables, except inguinal fat. Clusters 2 and 3 differed in $\mathrm{CCW}$, carcass muscle percentage ( $\mathrm{CaM} \%)$, carcass bone percentage $(\mathrm{CaB} \%)$, carcass fat percentage $(\mathrm{CaF} \%)$, kidney fat $(\mathrm{KiF})$, and pelvic fat (PelF).

A significant effect was found in the clusters for the score according to the EUS and BRS (Table 3), with a difference $(\mathrm{P}<0.05)$ among the carcasses grouped in clusters 4 and 1 for both systems. When those classification methods were used, only the carcasses with low fat content

\begin{tabular}{|c|c|}
\hline \multicolumn{2}{|l|}{ Variable } \\
\hline $\mathrm{CCW}$ & Cold carcass weight (kg) \\
\hline $\mathrm{CaM} \%$ & Carcass muscle $(\%)$ \\
\hline $\mathrm{CaB} \%$ & Carcass bone $(\%)$ \\
\hline $\mathrm{CaF} \%$ & Carcass fat $(\%)$ \\
\hline CaM:F & Carcass muscle:fat ratio \\
\hline $\mathrm{CaF}: \mathrm{B}$ & Carcass fat:bone ratio \\
\hline $\mathrm{KiF}$ & Kidney fat (g) \\
\hline PelF & Pelvic fat $(\mathrm{g})$ \\
\hline $\operatorname{IngF}$ & Inguinal fat $(\mathrm{g})$ \\
\hline $\mathrm{BFT}$ & Back fat thickness (mm) \\
\hline HiM\% $\%$ & Hindquarter muscle (\%) \\
\hline $\mathrm{HiB} \%$ & Hindquarter bone $(\%)$ \\
\hline $\mathrm{HiF} \%$ & Hindquarter fat (\%) \\
\hline HiM:F & Hindquarter muscle:fat ratio \\
\hline $\mathrm{HiF}: \mathrm{B}$ & Hindquarter fat:bone ratio \\
\hline $\mathrm{BaM} \%$ & Back muscle (\%) \\
\hline $\mathrm{BaB} \%$ & Back bone $(\%)$ \\
\hline $\mathrm{BaF} \%$ & Back fat $(\%)$ \\
\hline BaM:F & Back muscle:fat ratio \\
\hline $\mathrm{BaF}: \mathrm{B}$ & Back fat:bone ratio \\
\hline $\mathrm{ShM} \%$ & Shoulder muscle (\%) \\
\hline $\mathrm{ShB} \%$ & Shoulder bone $(\%)$ \\
\hline $\mathrm{ShF} \%$ & Shoulder fat (\%) \\
\hline ShM:F & Shoulder muscle:fat ratio \\
\hline ShF:B & Shoulder fat:bone ratio \\
\hline
\end{tabular}

Table 1 - Variables used in the cluster analysis to configure the classification tree 
$(\leq 19 \%)$ and those with high fat content $(\geq 28.7 \%), 20$ and 19, respectively, could be discriminated, enabling the discrimination of carcasses grouped at the top and bottom ends of those visual scoring systems: high-adiposity carcasses (cluster 4) from low-adiposity ones (cluster 1). Clusters 2 and 3 did not statistically differ between each other, neither did they differ from the top and bottom clusters $(\mathrm{P}>0.05)$, except cluster 3 and 4 from BRS.
Carcass groups were also established as a function of the score in both systems. Under the EUS, four scores $(1,2$, 3 , and 4) were obtained (Figure 2), while three (1, 2, and 3) were obtained by the BRS (Figure 3).

Using the EUS scale, a significant difference $(\mathrm{P}<0.05)$ was found in all carcass tissue composition variables between the poor (1) and very good (4) scores, except for carcass muscle (CaM\%), KiF, inguinal fat (IngF), and PelF,

\section{Dendrogram}

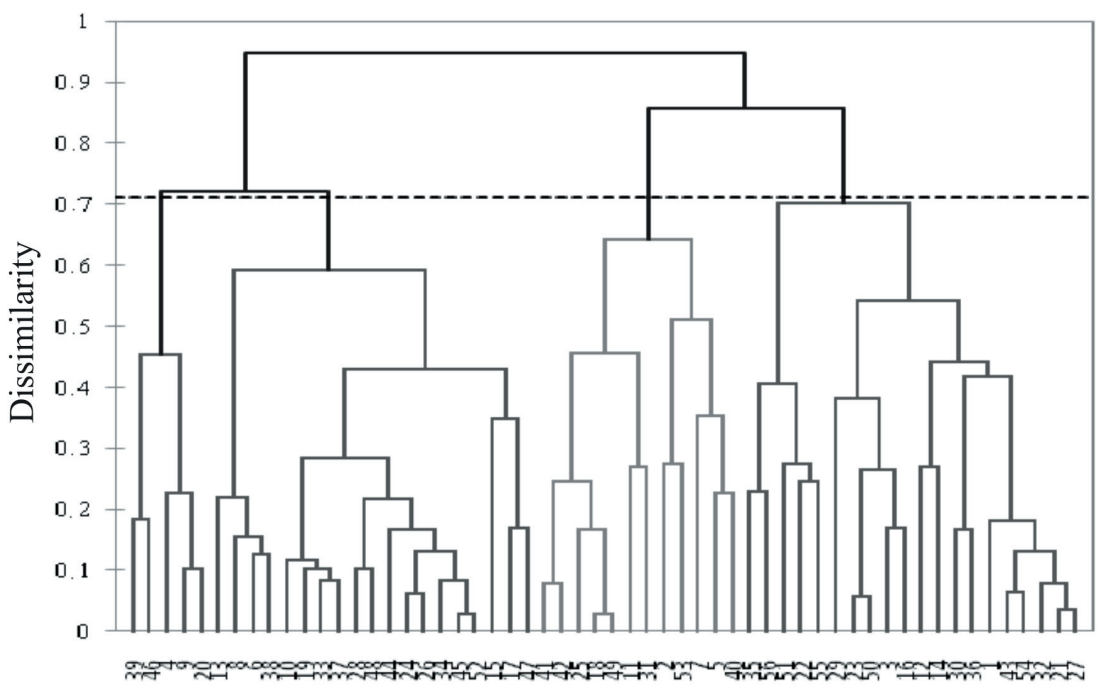

The $\mathrm{x}$ axis shows the numbers for carcass identification.

Figure 1 - Dendrogram (dissimilarity) showing the formation of four carcass groups defined by the amounts of fat and tissue composition.

Table 2 - Means and standard deviations of tissue composition and fat cover of carcasses and cuts defined by the four clusters formed by the classification tree

\begin{tabular}{|c|c|c|c|c|c|}
\hline & $1(\mathrm{n}=20)$ & $2(\mathrm{n}=12)$ & $3(n=5)$ & $4(\mathrm{n}=19)$ & P-value \\
\hline $\mathrm{CCW}$ & $15.59 \pm 0.48 b$ & $15.16 \pm 0.55 b$ & $20.10 \pm 0.71 \mathrm{a}$ & $20.19 \pm 0.49 \mathrm{a}$ & $<.0001$ \\
\hline $\mathrm{ShF} \%$ & $13.15 \pm 0.49 b$ & $15.17 \pm 1.27 \mathrm{~b}$ & $16.29 \pm 1.06 \mathrm{~b}$ & $21.00 \pm 0.66 \mathrm{a}$ & $<.0001$ \\
\hline $\mathrm{HiF} \%$ & $11.95 \pm 0.51 b$ & $14.36 \pm 0.83 b$ & $14.26 \pm 0.39 b$ & $17.20 \pm 0.49 \mathrm{a}$ & $<.0001$ \\
\hline $\mathrm{BaF} \%$ & $16.95 \pm 1.03 \mathrm{~b}$ & $19.09 \pm 1.03 \mathrm{ab}$ & $21.93 \pm 1.20 \mathrm{a}$ & $23.57 \pm 0.86 \mathrm{a}$ & $<.0001$ \\
\hline $\mathrm{CaM} \%$ & $59.47 \pm 0.63 \mathrm{a}$ & $54.53 \pm 0.79 \mathrm{c}$ & $57.88 \pm 0.25 \mathrm{ab}$ & $55.81 \pm 0.47 \mathrm{bc}$ & $<.0001$ \\
\hline $\mathrm{CaB} \%$ & $19.97 \pm 0.47 \mathrm{ab}$ & $21.44 \pm 0.78 \mathrm{a}$ & $17.8 \mathrm{~b} \pm 0.78 \mathrm{c}$ & $16.73 \pm 0.23 c$ & $<.0001$ \\
\hline $\mathrm{CaF} \%$ & $19.66 \pm 0.68 b$ & $22.48 \pm 1.12 b$ & $27.25 \pm 0.81 \mathrm{a}$ & $28.68 \pm 0.67 \mathrm{a}$ & $<.0001$ \\
\hline $\mathrm{KiF}$ & $0.21 \pm 0.02 b$ & $0.17 \pm 0.02 b$ & $0.47 \pm 0.02 \mathrm{a}$ & $0.42 \pm 0.04 \mathrm{a}$ & $<.0001$ \\
\hline PelF & $0.09 \mathrm{~b} \pm 0.01 \mathrm{c}$ & $0.06 \pm 0.02 \mathrm{c}$ & $0.28 \pm 0.02 \mathrm{a}$ & $0.18 \pm 0.03 b$ & $<.0001$ \\
\hline IngF & $0.06 \pm 0.01$ & $0.07 \pm 0.02$ & $0.07 \pm 0.01$ & $0.12 \pm 0.02$ & NS \\
\hline BFT & $2.14 \pm 0.20 b$ & $2.45 \pm 0.40 \mathrm{~b}$ & $3.55 \pm 0.54 \mathrm{ab}$ & $4.50 \pm 0.36 \mathrm{a}$ & $<.0001$ \\
\hline
\end{tabular}

$\mathrm{CCW}$ - cold carcass weight ( $\mathrm{kg}) ; \mathrm{ShF} \%$ - shoulder fat (\%); $\mathrm{HiF} \%$ - hindquarter fat (\%); $\mathrm{BaF} \%$ - back fat (\%); CaM $\%$ - carcass muscle ( $\%) ; \mathrm{CaB} \%$ - carcass bone ( $\%)$; $\mathrm{CaF} \%$ - carcass fat (\%); KiF - kidney fat (g); PelF - pelvic fat (g); IngF - inguinal fat (g); BFT - back fat thickness (mm); NS - not significant.

The same letters on the same row do not differ $(\mathrm{P}<0.05)$ according to Tukey's test.

Table 3 - Means and standard deviations of the scores by the classification systems defined by the four clusters formed by the classification tree

\begin{tabular}{lcccc}
\hline & $1(\mathrm{n}=20)$ & $2(\mathrm{n}=12)$ & $3(\mathrm{n}=5)$ & $4(\mathrm{n}=19)$ \\
\hline EUS & $2.00 \pm 0.13 \mathrm{~b}$ & $2.33 \pm 0.19 \mathrm{ab}$ & $2.2 \pm 0.20 \mathrm{ab}$ & $2.79 \pm 0.18 \mathrm{a}$ \\
BRS & $1.55 \pm 0.11 \mathrm{~b}$ & $2.25 \pm 0.33 \mathrm{ab}$ & $2.00 \pm 0.00 \mathrm{~b}$ & 0.0052 \\
\hline
\end{tabular}

EUS - European classification system of lamb carcasses; BRS - Brazilian classification system of lamb carcasses.

The same letters on the same row do not differ $(\mathrm{P}<0.05)$ according to Tukey's test. 


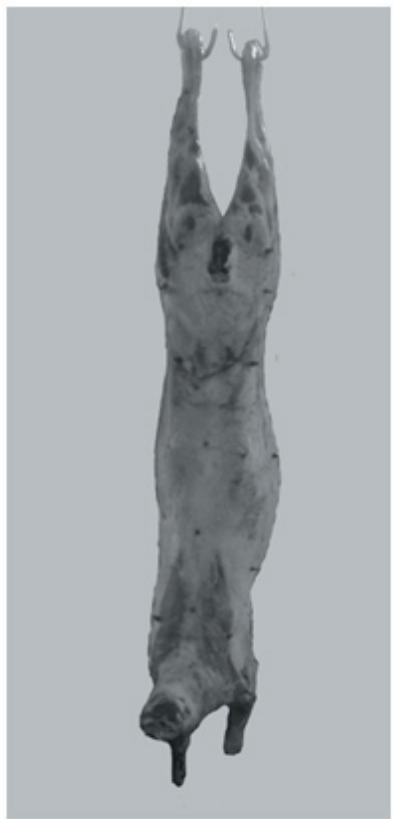

1

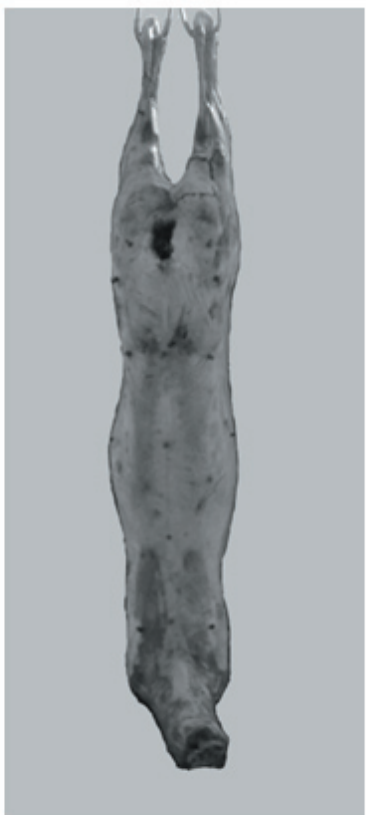

2

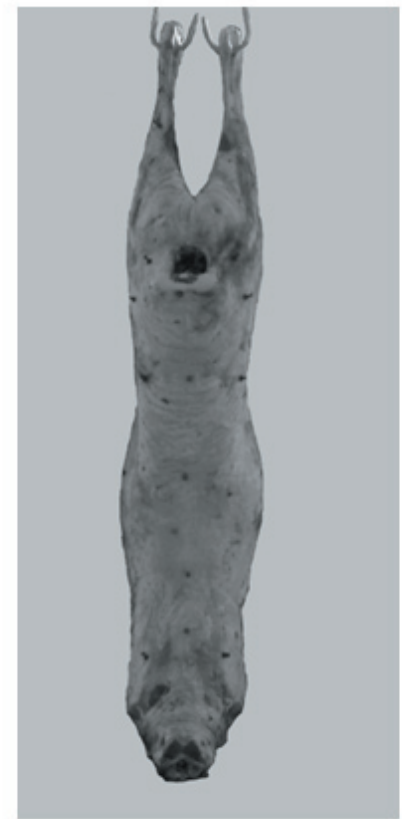

3

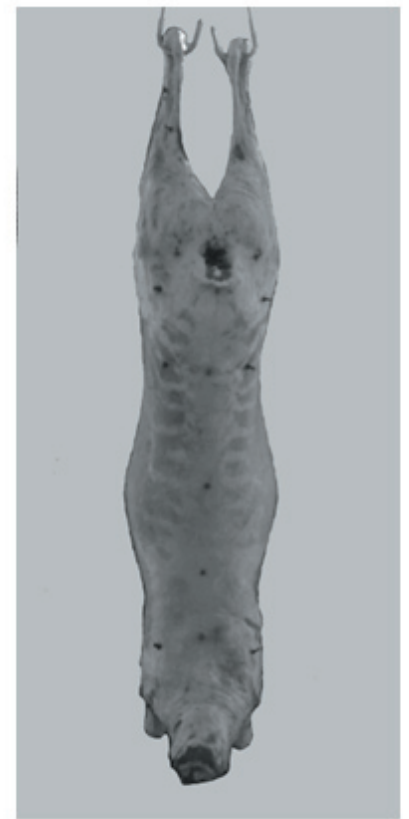

4

1: poor; 2: fair; 3: good; 4: very good.

Figure 2 - Photographic standards used in the score scale by the European lamb carcass classification system to assess the degree of fat cover in woolless lambs.
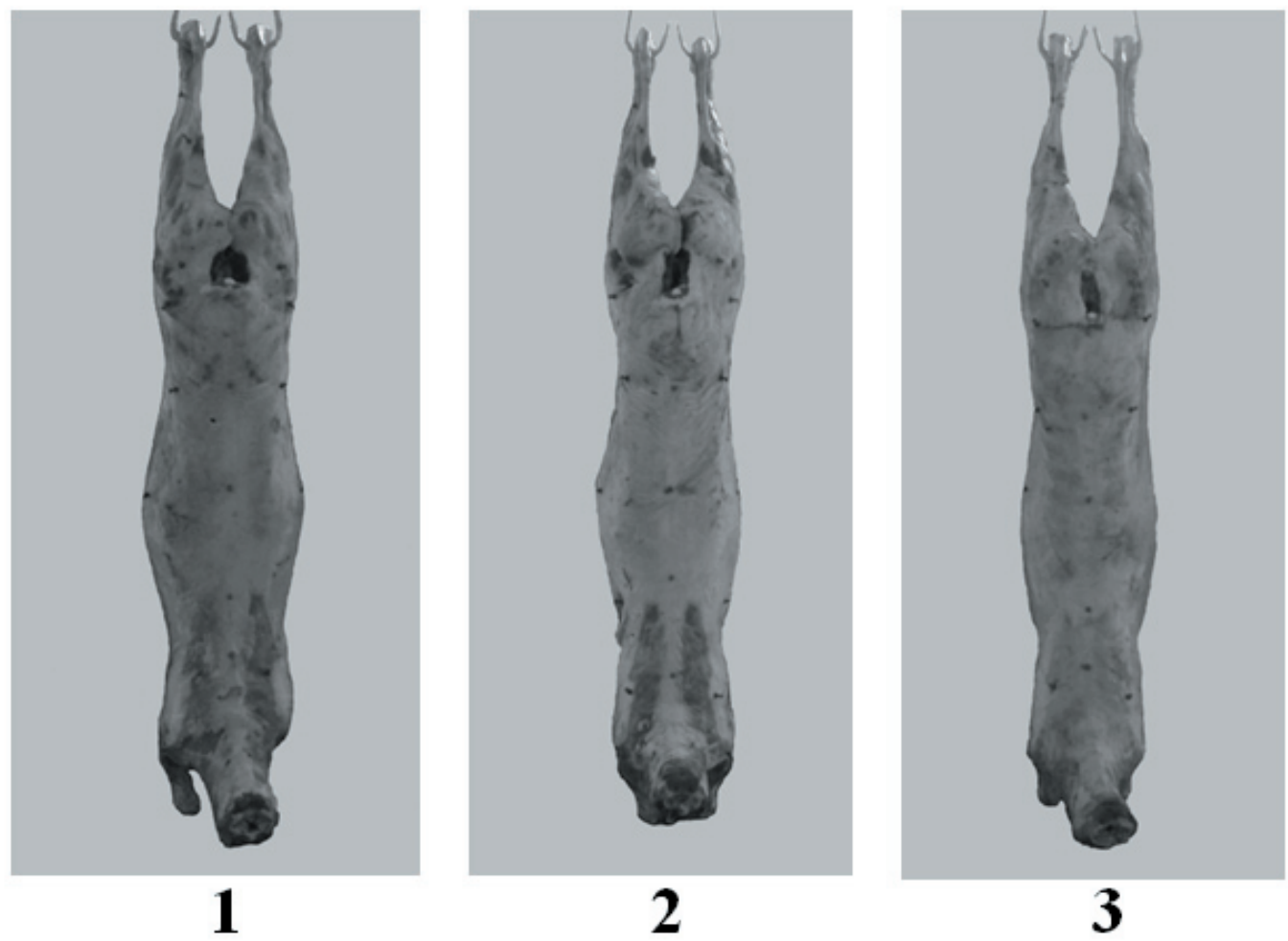

1: lean; 2: slight fat; 3 : average fat.

Figure 3 - Photographic standards used in the score scale by the Brazilian lamb carcass classification system to assess the degree of fat cover in woolless lambs. 
which were not significant. According to the BRS scale, a significant difference $(\mathrm{P}<0.05)$ was found between the lean (1) and average fat (3) for all variables, except for $\mathrm{CaM} \%$ and IngF (Table 4).

The correlation analysis was performed among scores of both systems and the tissue composition variables of the carcass (Table 5). When the EUS was used, significant correlations were found for all variables, except for inguinal fat. Using the BRS, significant correlations were found for the same variables, except for inguinal fat and $\mathrm{CaM} \%$. When the two scales were compared, the BRS method showed the highest correlation coefficients for most variables. When the grouped data were analyzed, nearly all carcass tissue composition variables had higher correlation coefficients with BFT than the subjective fat assessment methods.
The regression analysis (Table 6) confirms that both classification systems were similar regarding carcass tissue composition prediction in slaughter conditions. When $\mathrm{CCW}$ was used in the model along with the score obtained by the BRS, $68 \%$ of the variation obtained for $\mathrm{CaF} \%$ was explained.

Both carcass classification systems defined by the EUS and BRS were significantly different $(\mathrm{P}<0.05)$ regarding hindquarter fat $(\mathrm{HiF} \%)$ and the hindquarter muscle:fat (HiM:F) and hindquarter fat:bone (HiF:B) ratios (Table 7).

Significant differences were found for those variables between the poor (1) and very good (4) scores for HiF\%. The groups very good (4) and good (3) were similar to each other, but significantly different from the group poor (1). No significant differences were found between groups of

Table 4 - Means and standard deviations of carcass weight, tissue composition, and fat cover defined by the groups according to the score obtained by the European (EUS) and Brazilian (BRS) lamb carcass classification systems

\begin{tabular}{|c|c|c|c|c|c|}
\hline & \multicolumn{4}{|c|}{ EUS } & \multirow{2}{*}{ P-value } \\
\hline & $1(n=5)$ & $2(\mathrm{n}=29)$ & $3(n=19)$ & $4(n=3)$ & \\
\hline $\mathrm{CCW}$ & $14.40 \pm 0.74 b$ & $17.18 \pm 0.57 \mathrm{ab}$ & $18.3 \pm 0.68 \mathrm{ab}$ & $20.08 \pm 1.59 \mathrm{a}$ & 0.028 \\
\hline CaM\% & $58.74 \pm 24.96$ & $57.45 \pm 0.56$ & $56.38 \pm 0.53$ & $54.19 \pm 0.61$ & NS \\
\hline $\mathrm{CaB} \%$ & $21.30 \pm 1.14 \mathrm{a}$ & $19.25 \pm 0.51 \mathrm{ab}$ & $18.1 \pm 0.46 \mathrm{ab}$ & $16.44 \pm 0.60 \mathrm{~b}$ & 0.0225 \\
\hline $\mathrm{CaF} \%$ & $18.67 \pm 1.76 \mathrm{c}$ & $22.88 \pm 0.78 b c$ & $26.14 \pm 1.13 \mathrm{ab}$ & $30.25 \pm 1.09 a$ & 0.0007 \\
\hline CaM:F & $3.24 \pm 0.27 \mathrm{a}$ & $2.60 \pm 0.10 \mathrm{ab}$ & $2.25 \pm 0.13 b c$ & $1.79 \pm 0.05 \mathrm{c}$ & 0.0007 \\
\hline $\mathrm{CaF}: \mathrm{B}$ & $0.90 \pm 0.14 \mathrm{c}$ & $1.23 \pm 0.06 \mathrm{bc}$ & $1.48 \pm 0.09 \mathrm{ab}$ & $1.85 \pm 0.14 \mathrm{a}$ & 0.0008 \\
\hline BFT & $1.30 \pm 0.19 \mathrm{c}$ & $2.61 \pm 0.19 b c$ & $3.99 \pm 0.36 \mathrm{ab}$ & $5.86 \pm 1.45 \mathrm{a}$ & $<.0001$ \\
\hline $\mathrm{KiF}$ & $0.19 \pm 0.06$ & $0.27 \pm 0.03$ & $0.35 \pm 0.04$ & $0.34 \pm 0.07$ & NS \\
\hline PelF & $0.06 \pm 0.02$ & $0.12 \pm 0.02$ & $0.16 \pm 0.03$ & $0.21 \pm 0.03$ & NS \\
\hline $\operatorname{IngF}$ & $0.08 \pm 0.05$ & $0.08 \pm 0.01$ & $0.09 \pm 0.02$ & $0.03 \pm 0.01$ & NS \\
\hline
\end{tabular}

\begin{tabular}{|c|c|c|c|c|}
\hline & & BRS & & \\
\hline & $1(\mathrm{n}=12)$ & $2(\mathrm{n}=31)$ & $3(\mathrm{n}=13)$ & P-value \\
\hline $\mathrm{CCW}$ & $14.39 \pm 0.49 b$ & $17.81 \pm 0.52 \mathrm{a}$ & $19.48 \pm 0.67 \mathrm{a}$ & $<.0001$ \\
\hline CaM\% & $57.79 \pm 1.39$ & $57.27 \pm 0.47$ & $55.74 \pm 0.50$ & NS \\
\hline $\mathrm{CaB} \%$ & $20.34 \pm 0.78 \mathrm{a}$ & $19.02 \pm 0.47 \mathrm{ab}$ & $17.26 \pm 0.47 b$ & 0.01 \\
\hline $\mathrm{CaF} \%$ & $19.09 \pm 0.88 \mathrm{c}$ & $23.91 \pm 0.78 b$ & $28.75 \pm 0.89 a$ & $<.0001$ \\
\hline CaM:F & $30.84 \pm 0.13 a$ & $24.89 \pm 0.10 b$ & $19.68 \pm 0.08 \mathrm{c}$ & $<.0001$ \\
\hline $\mathrm{CaF}: \mathrm{B}$ & $0.96 \pm 0.06 \mathrm{c}$ & $1.30 \pm 0.06 \mathrm{~b}$ & $1.69 \pm 0.09 \mathrm{a}$ & $<.0001$ \\
\hline BFT & $1.76 \pm 0.22 \mathrm{c}$ & $2.91 \pm 0.22 b$ & $4.93 \pm 0.45 \mathrm{a}$ & $<.0002$ \\
\hline $\mathrm{KiF}$ & $0.18 \pm 0.02 \mathrm{~b}$ & $0.29 \pm 0.03 \mathrm{ab}$ & $0.40 \pm 0.06 \mathrm{a}$ & 0.0019 \\
\hline PelF & $0.08 \pm 0.01 \mathrm{~b}$ & $0.13 \pm 0.02 \mathrm{ab}$ & $0.18 \pm 0.04 \mathrm{a}$ & 0.0454 \\
\hline IngF & $0.04 \pm 0.018$ & $0.09 \pm 0.01$ & $0.11 \pm 0.03$ & NS \\
\hline
\end{tabular}

$\mathrm{CCW}$ - cold carcass weight $(\mathrm{kg})$; $\mathrm{CaM} \%$ - carcass muscle (\%); CaB\% - carcass bone (\%); CaF\% - carcass fat (\%); CaM:F - carcass muscle:fat ratio; CaF:B - carcass fat:bone ratio; BFT - back fat thickness (mm); KiF - kidney fat (g); PelF - pelvic fat (g); IngF - inguinal fat (g); NS - not significant.

The same letters on the same row do not differ $(\mathrm{P}<0.05)$ according to Tukey's test.

Table 5 - Correlation coefficients between the scores obtained by the European (EUS) and Brazilian (BRS) classification systems and by back fat thickness and carcass tissue and fat compositions

\begin{tabular}{|c|c|c|c|c|c|c|c|c|c|}
\hline & $\mathrm{CCW}$ & CaM\% & $\mathrm{CaB} \%$ & $\mathrm{CaF} \%$ & CaM:F & $\mathrm{CaF}: \mathrm{B}$ & $\mathrm{KiF}$ & IngF & PelF \\
\hline EUS & $0.38 * *$ & $-0.31 *$ & $-0.40 * *$ & $0.53 * * *$ & $-0.52 * * *$ & $0.52 * * *$ & $0.30 *$ & $-0.02 \mathrm{NS}$ & $0.34 * *$ \\
\hline BRS & $0.50 * * *$ & $-0.24 \mathrm{NS}$ & $-0.40 * *$ & $0.63 * * *$ & $-0.59 * * *$ & $0.61 * * *$ & $0.44 * * *$ & $0.26 \mathrm{NS}$ & $0.32 *$ \\
\hline BFT & $0.72 * * *$ & $-0.19 \mathrm{NS}$ & $-0.62 * * *$ & $0.74 * * *$ & $-0.67 * * *$ & $0.78 * * *$ & $0.6^{* * *}$ & $0.16^{* * *}$ & $0.56 * * *$ \\
\hline
\end{tabular}

$\mathrm{CCW}$ - cold carcass weight (kg); CaM\% - carcass muscle (\%); CaB\% - carcass bone (\%); CaF\% - carcass fat (\%); CaM:F - carcass muscle:fat ratio; CaF:B - carcass fat:bone ratio; $\mathrm{KiF}$ - kidney fat (g); IngF - inguinal fat (g); PelF - pelvic fat (g); BFT - back fat thickness (mm); NS - not significant.

$* \mathrm{P} \leq 0.05$.

$* * \mathrm{P} \leq 0.01$.

$* * * \mathrm{P} \leq 0.001$. 
Table 6 - Regression coefficient (R), coefficient of determination $\left(\mathrm{R}^{2}\right)$, and probability $(\mathrm{P})$ between the classification systems associated with back fat thickness (BFT), cold carcass weight $(\mathrm{CCW})$, and carcass measurements

\begin{tabular}{lcccc}
\hline & & $\mathrm{CaM} \%$ & $\mathrm{CaB} \%$ & $\mathrm{CaF} \%$ \\
\hline $\mathrm{y}=$ EUS & $\mathrm{R}$ & 0.30 & 0.40 & 0.53 \\
& $\mathrm{R}^{2}$ & 0.09 & 0.16 & 0.28 \\
& $\mathrm{P}$ & 0.02 & $<.0001$ & $<.0001$ \\
$\mathrm{y}=$ EUS+BFT & $\mathrm{R}$ & 0.30 & 0.62 & 0.75 \\
& $\mathrm{R}^{2}$ & 0.09 & 0.39 & 0.56 \\
& $\mathrm{P}$ & 0.07 & $<.0001$ & $<.0001$ \\
$\mathrm{y}=$ EUS+CCW & $\mathrm{R}$ & 0.30 & 0.69 & 0.81 \\
& $\mathrm{R}^{2}$ & 0.09 & 0.47 & 0.66 \\
& $\mathrm{P}$ & 0.07 & $<.0001$ & $<.0001$ \\
$\mathrm{y}=$ BRS & $\mathrm{R}$ & 0.24 & 0.40 & 0.63 \\
& $\mathrm{R}^{2}$ & 0.06 & 0.16 & 0.40 \\
& $\mathrm{P}$ & 0.08 & 0.00 & $<.0001$ \\
$\mathrm{y}=$ BRS+BFT & $\mathrm{R}$ & 0.24 & 0.62 & 0.77 \\
& $\mathrm{R}^{2}$ & 0.06 & 0.39 & 0.59 \\
& $\mathrm{P}$ & 0.20 & $<.0001$ & $<.0001$ \\
$\mathrm{y}=$ BRS+CCW & $\mathrm{R}$ & 0.24 & 0.67 & 0.82 \\
& $\mathrm{R}^{2}$ & 0.06 & 0.45 & 0.68 \\
& $\mathrm{P}$ & 0.22 & $<.0001$ & $<.0001$ \\
\hline
\end{tabular}

EUS - European classification system of lamb carcasses; BRS - Brazilian classification system of lamb carcasses; $\mathrm{CaM} \%$ - carcass muscle (\%); $\mathrm{CaB} \%$ carcass bone (\%); $\mathrm{CaF} \%$ - carcass fat $(\%)$. scores 4 and 3 (good) for HiM:F and HIF:B according to the EUS. In BRS, significant differences were found for those variables between the lean (1) and average fat (3) scores for hindquarter bone (HiB\%) and the group slight fat (2) was significantly different from the group poor (1).

The correlation analysis (Table 8) showed that both methods were good predictors of hindquarter tissue compositions. The BRS yielded higher correlation coefficients for most variables. Backfat thickness correlated well with all hindquarter variables, except for hindquarter muscle (HiM\%), which was not significant.

Both groups showed significant difference for shoulder fat $(\mathrm{ShF} \%)$ and shoulder muscle:fat (ShM:F) and shoulder fat:bone ratios (ShF:B), while only the BRS showed difference for shoulder bone (ShB\%) (Table 9). The groups of extreme scores significantly differed for all variables in both classification systems. The groups with scores fair (2) and good (3) did not differ for any variables in the EUS. For the BRS system, no statistically significant difference was found between the groups lean (1) and slight fat (2) for the variables ShB\%, ShM:F, and ShF:B.

Table 7 - Means and standard deviations of hindquarter tissue composition defined by the groups according to the score obtained by the European (EUS) and Brazilian (BRS) lamb carcass classification systems

\begin{tabular}{|c|c|c|c|c|c|}
\hline & \multicolumn{4}{|c|}{ EUS } & \multirow{2}{*}{ P-value } \\
\hline & $1(\mathrm{n}=5)$ & $2(\mathrm{n}=29)$ & $3(\mathrm{n}=19)$ & $4(n=3)$ & \\
\hline HiM \% & $64.77 \pm 2.36$ & $65.05 \pm 0.83$ & $64.13 \pm 0.81$ & $61.32 \pm 0.83$ & NS \\
\hline $\mathrm{HiB} \%$ & $19.23 \pm 0.94$ & $17.02 \pm 0.49$ & $17.02 \pm 0.31$ & $15.99 \pm 0.39$ & NS \\
\hline $\mathrm{HiF} \%$ & $10.97 \pm 1.2 \mathrm{c}$ & $13.59 \pm 0.47 b c$ & $15.89 \pm 0.62 \mathrm{ab}$ & $19.51 \pm 0.67 \mathrm{a}$ & $<.0001$ \\
\hline HiM:F & $6.17 \pm 0.65 \mathrm{a}$ & $4.99 \pm 0.22 \mathrm{ab}$ & $4.2 \pm 0.22 \mathrm{bc}$ & $3.15 \pm 0.11 \mathrm{c}$ & 0.0009 \\
\hline $\mathrm{HiF}: \mathrm{B}$ & $0.58 \pm 0.08 \mathrm{c}$ & $0.82 \pm 0.04 b c$ & $0.97 \pm 0.05 \mathrm{ab}$ & $1.20 \pm 0.06 \mathrm{a}$ & 0.0002 \\
\hline
\end{tabular}
BRS

\begin{tabular}{|c|c|c|c|c|}
\hline & $1(\mathrm{n}=12)$ & $2(\mathrm{n}=31)$ & $3(\mathrm{n}=13)$ & P-value \\
\hline HiM\% & $65.79 \pm 2.03$ & $64.89 \pm 0.55$ & $62.43 \pm 0.49$ & NS \\
\hline $\mathrm{HiB} \%$ & $18.86 \pm 0.75 \mathrm{a}$ & $16.63 \pm 0.38 b$ & $16.3 \pm 0.36 b$ & 0.004 \\
\hline $\mathrm{HiF} \%$ & $11.83 \pm 0.69 \mathrm{c}$ & $14.17 \pm 0.49 b$ & $17.56 \pm 0.51 \mathrm{a}$ & $<.0001$ \\
\hline $\mathrm{HiF}: \mathrm{B}$ & $0.64 \pm 0.05 \mathrm{c}$ & $0.87 \pm 0.04 b$ & $1.09 \pm 0.05 \mathrm{a}$ & $<.0001$ \\
\hline HiM:F & $57.58 \pm 0.35 \mathrm{a}$ & $48.03 \pm 0.22 b$ & $35.95 \pm 0.12 \mathrm{c}$ & $<.0001$ \\
\hline
\end{tabular}

HiM\% - hindquarter muscle (\%); HiB\% - hindquarter bone (\%); HiF\% - hindquarter fat (\%); HiF:B - hindquarter fat:bone ratio; HiM:F - hindquarter muscle:fat ratio; NS = not significant.

The same letters in the same column do not differ $(\mathrm{P}<0.05)$ according to Tukey's test.

Table 8 - Correlation coefficients between the scores obtained by the European (EUS) and Brazilian (BRS) classification systems and by back fat thickness (BFT) and hindquarter tissue compositions

\begin{tabular}{|c|c|c|c|c|c|}
\hline & $\mathrm{HiM} \%$ & $\mathrm{HiB} \%$ & $\mathrm{HiF} \%$ & HiM:F & HiF:B \\
\hline EUS & $-0.17 \mathrm{NS}$ & $-0.28 *$ & $0.60 * * *$ & $-0.52 * * *$ & $0.56^{* * *}$ \\
\hline BRS & $-0.29 *$ & $-0.32 * *$ & $0.62 * * *$ & $-0.56^{* * *}$ & $0.60 * * *$ \\
\hline BFT & $-0.19 \mathrm{NS}$ & $-0.41 * *$ & $0.67 * * *$ & $-0.59 * * *$ & $0.69 * * *$ \\
\hline
\end{tabular}

HiM\% - hindquarter muscle (\%); HiB\% - hindquarter bone (\%); HiF\% - hindquarter fat (\%); HiM:F - hindquarter muscle:fat ratio; HiF:B - hindquarter fat:bone ratio; NS - not significant.

$* \mathrm{P} \leq 0.05$.

** $\mathrm{P} \leq 0.01$.

$* * * \mathrm{P} \leq 0.001$. 
The correlation analysis (Table 10) showed a significant correlation for all shoulder tissue composition variables, except for ShM\% in both classification systems. The BRS was the best predictor of shoulder tissue composition, with higher correlation coefficients. When the correlation coefficients of the shoulder were compared with those of the hindquarter according to the EUS, the latter were higher. However, in the BRS, the correlation coefficients were higher for the shoulder. Backfat thickness was the best predictor only for $\mathrm{ShF}: \mathrm{B}$ and $\mathrm{ShB} \%$, while the BRS was the best predictor for the remaining variables.

Both groups of systems significantly differed for backfat $(\mathrm{BaF} \%)$, back muscle:fat ratio (BaM:F), and backfat:bone ratio (BaF:B) (Table 11). The Brazilian and

Table 9 - Means and standard deviations of shoulder tissue composition defined by the groups according to the score obtained by the European (EUS) and Brazilian (BRS) lamb carcass classification systems

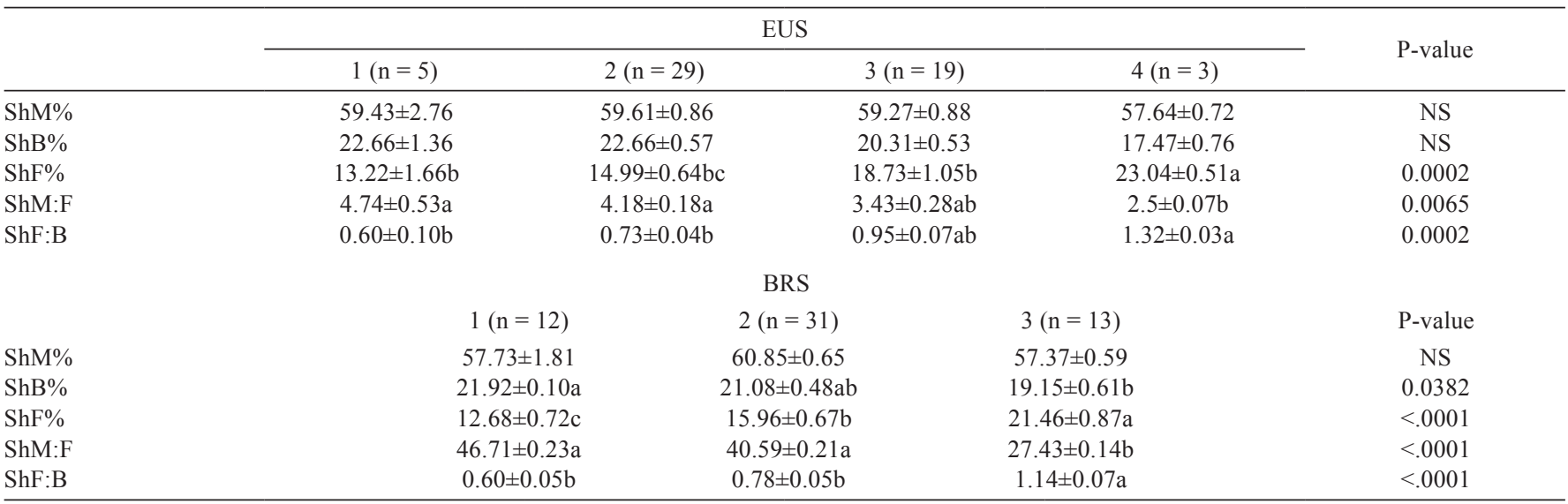

ShM \% - shoulder muscle (\%); ShB\% - shoulder bone (\%); ShF\% - shoulder fat (\%); ShM:F - shoulder muscle:fat ratio; ShF:B - shoulder fat:bone ratio; NS - not significant. The same letters in the same column do not differ $(\mathrm{P}<0.05)$ according to Tukey's test.

Table 10 - Correlation coefficients between the scores obtained by the European (EUS) and Brazilian (BRS) classification systems and by back fat thickness (BFT) and shoulder tissue compositions

\begin{tabular}{lllll}
\hline & ShM $\%$ & ShB $\%$ & ShF\% & ShM:F \\
\hline EUS & $-0.07 \mathrm{NS}$ & $-0.33 *$ & $0.55 * * *$ & $-0.45 * * *$ \\
BRS & $-0.13 \mathrm{NS}$ & $-0.34 * *$ & $0.67 * * *$ & $-0.58 * * *$ \\
BFT & $-0.04 \mathrm{NS}$ & $-0.47 * * *$ & $0.65 * * *$ & $0.63 * * *$ \\
\hline
\end{tabular}

ShM\% - shoulder muscle (\%); ShB\% - shoulder bone (\%); ShF\% - shoulder fat (\%); ShF:B - shoulder fat:bone ratio; ShM:F - shoulder muscle:fat ratio; NS - not significant. $* \mathrm{P} \leq 0.05$.

$* * \mathrm{P} \leq 0.01$.

$* * * \mathrm{P} \leq 0.001$

Table 11 - Means and standard deviations of back tissue composition defined by the groups according to the score obtained by the European (EUS) and Brazilian (BRS) lamb carcass classification systems

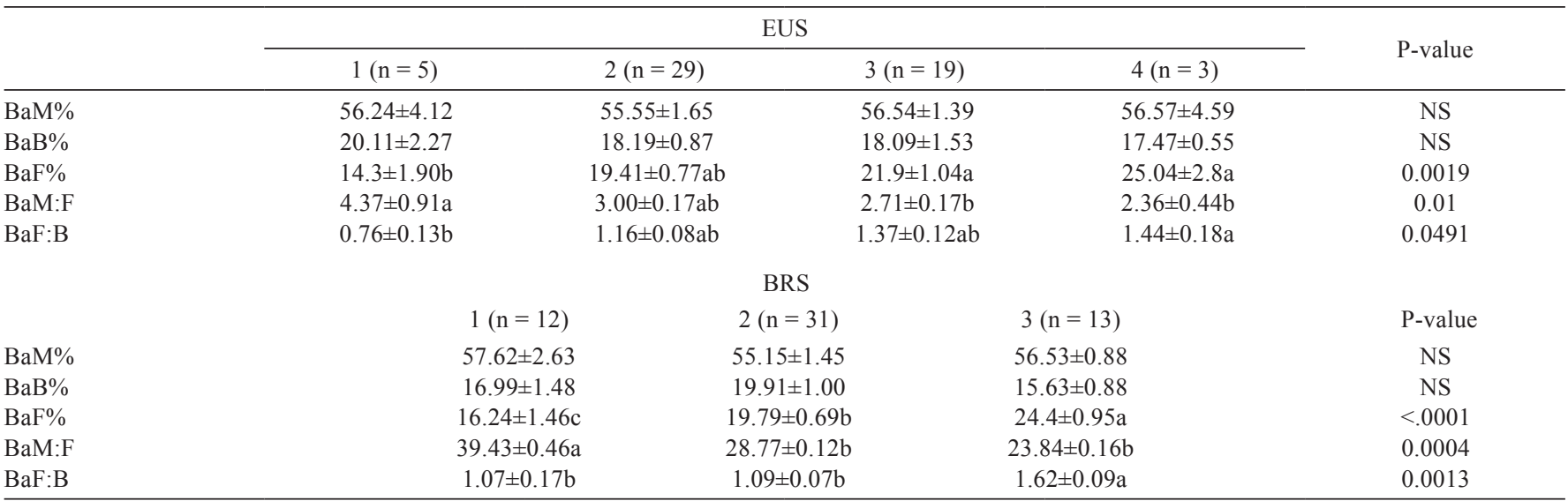

$\mathrm{BaM} \%$ - back muscle (\%); BaB\% - back bone (\%); BaF\% - back fat (\%); BaF:B - back fat:bone ratio; BaM:F - back muscle:fat ratio; NS - not significant. The same letters on the same row do not differ $(\mathrm{P}<0.05)$ according to Tukey's test. 
Table 12 - Correlation coefficients between the scores obtained by the European (EUS) and Brazilian (BRS) classification systems and by the back fat thickness (BFT) and back tissue composition

\begin{tabular}{lccccc}
\hline & ShM $\%$ & ShB $\%$ & ShF\% & ShM:F & ShF:B \\
\hline EUS & $0.04 \mathrm{NS}$ & $-0.08 \mathrm{NS}$ & $0.48^{* * *}$ & $-0.38^{* *}$ & $0.35^{* *}$ \\
BRS & $-0.01 \mathrm{NS}$ & $-0.18 \mathrm{NS}$ & $0.57^{* * *}$ & $-0.44^{* * *}$ & $0.44^{* * *}$ \\
BFT & $0.06 \mathrm{NS}$ & $-0.34^{* *}$ & $0.62^{* * *}$ & $-0.44^{* * *}$ & $0.51^{* * *}$ \\
\hline
\end{tabular}

$\mathrm{BaM} \%$ - back muscle (\%); BaB\% - back bone (\%); BaF\% - back fat (\%); BaF:B - back fat:bone ratio; BaM:F - back muscle:fat ratio; NS - not significant.

$* \mathrm{P} \leq 0.05$.

$* * \mathrm{P} \leq 0.01$.

$* * * \mathrm{P} \leq 0.001$.

European classification systems enabled differentiating back tissue composition classified for carcasses with score extremes, while no such distinction was possible between the intermediate levels for those parameters.

Groups 1, 2, and 3 differed regarding $\mathrm{BaF} \%$, while for BaM:F, groups 2 and 3 did not differ. For BaF:B, no difference was found between groups 1 and 2 for the BRS. None of the groups differed in muscle percentage or bone percentage. The correlation analysis (Table 12) showed that the EUS and BRS were significantly correlated with fat percentage $(\mathrm{BaF} \%)$ and with $\mathrm{BaM}: \mathrm{F}$ and $\mathrm{BaF}: \mathrm{B}$. Neither method of classification was significantly correlated with back muscle $(\mathrm{BaM} \%)$ or back bone $(\mathrm{BaB} \%)$. Backfat thickness was better correlated with $\mathrm{BaF} \%, \mathrm{BaF}: \mathrm{B}$, and $\mathrm{BaB} \%$ than any score of the classification systems.

\section{Discussion}

Based on 25 carcass tissue composition variables and three cuts, the clustering analysis found four carcass groups, which significantly differed for most variables. Even clusters 2 and 3 were similar to the top and bottom (1 and 4) groups for the characteristics evaluated, which suggests difficulty in discriminating intermediate carcasses regarding tissue composition.

The use of specialized meat sheep breeds provides good carcass conformation, with higher scores according to classification and grading systems, unlike hair sheep breeds. Although the latter have low carcass conformation, Souza et al. (2016) found no difference in body score of Santa Inês, $1 / 2$ Dorper $\times$ Santa Inês and $3 / 4$ Dorper $\times$ Santa Inês lambs. Garcia et al. (2010) reported similarity between quantitative variables of Santa Inês, Texel $\times$ Santa Inês, and Dorper $\times$ Santa Inês lambs, corroborating the results obtained in the present study, which found no difference among the groups analyzed regarding $\mathrm{CCW}$, tissue composition, or fat cover.

Carcass classification methods based on photographic standards have been used for a long time and are precise enough to set carcass prices based on muscle, fat, and bone percentages (Johansen et al., 2006). However, the European method was developed to assess carcasses of breeds more specialized in meat production and is not specific for carcasses from hair sheep animals commonly found in Brazil, which are little studied and evaluated compared with the number of studies on specialized breeds (Araújo Filho et al., 2010). The degree of fat cover is measured mainly in the shoulder and hindquarter, which explains why the scores using the BRS are better correlated with the amounts of fat in those areas than the EUS.

The evaluation of this development may be described by allometric lines, which are quite similar to actual values when assessed from birth to maturity or over long periods, based on growth as a function of weight and not necessarily time (Berg and Butterfield, 1966). Physiological maturity of each tissue differs at distinct animal development phases, with earlier development of bone, intermediate development of muscle, and late development of fat (Hammond, 1965). In lambs, growth is influenced by weight at birth and quality of the milk consumed in the suckling phase (Boucinhas et al., 2006), as well as the rearing system and post-weaning diet.

The visual standards used by either method in this study allow for good discrimination between lean and fat carcasses, but not for carcasses with intermediate degrees of fat cover. Along with subcutaneous fat development, they are good predictors of fat deposits and total fat development.

Despite the European system featuring four carcass score groups, no significant difference was obtained for carcass or cut tissue composition between the intermediate groups. The correlation with those variables was not as substantial as that obtained by the Brazilian classification system, which matches Huidobro et al. (2004), who obtained lower correlations with tissue composition using the European photographic scale for light lamb carcasses.

Both methods were able to predict carcass fat percentage; however, when BFT and CCW are included in 
the model, carcass tissue composition prediction becomes more viable, particularly for $\mathrm{CaF} \%$. It must be pointed out that establishing quality and profitability parameters for carcasses using BFT is desirable, since this is a usual and simple characteristic that can be measured in vivo through ultrasound. However, carcass fat must be assessed in abattoirs in a simple and quick fashion without using destructive methods. Although this measurement may be a better predictor when associated with subjective methods of tissue composition evaluation (Miguel et al., 2003), it is difficult to be applied, since it requires refrigeration for $24 \mathrm{~h}$, besides carcass handling and cutting, which becomes costly for the slaughter line.

Using BFT enabled a better discrimination of carcasses, with high significant correlation with nearly all tissue compositions, both of carcasses and cuts. Nonetheless, this attribute required prior carcass refrigeration for at least $24 \mathrm{~h}$ and a cut made in the backfat. This evaluation is difficult and costly for slaughter conditions, which makes the use of visual standards and cold carcass weight more accurate to discriminate intermediate fat cover classes.

Given that fat percentage increases with $\mathrm{CCW}$, further studies using weight classes are suggested to better understand the scores by both the EUS and BRS for woolless lamb carcasses. Russo et al. (2003), in a study on light lamb carcasses $(\leq 13 \mathrm{~kg}$ ), observed that CCW significantly differed regarding tissue composition variables when using photographic parameters. Those authors also stated that heavier carcasses have more adiposity than lighter ones. Miguel et al. (2007) found a statistically significant difference among $\mathrm{CCW}$ classes regarding carcass conformation scores when using the EUS (0.25-point scale), with higher scores for the heavier class $(14 \mathrm{~kg})$. Moreover, the results obtained show that better prediction of lamb carcass tissue composition would be achieved if the BRS and CCW were used.

\section{Conclusions}

The inclusion of objective methods (backfat thickness and cold carcass weight) in the subjective evaluation to determine the tissue composition of sheep carcasses allows a better classification without compromising the dynamics of the slaughter line. The Brazilian classification system of lamb carcasses is the best predictor of carcass tissue composition when associated with cold carcass weight for carcasses from hair sheep (Santa Inês) and crossbred (Santa Inês $\times$ Dorper) animals.

\section{Acknowledgments}

Funding was provided by the Coordenação de Aperfeiçoamento de Pessoal de Nível Superior (Capes) in project Pró-Amazônia: Biodiversidade e Sustentabilidade.

\section{References}

Araújo Filho, J. T.; Costa, R. G.; Fraga, A. B.; Sousa, W. D.; Cezar, M. F. and Batista, A. S. M. 2010. Desempenho e composição da carcaça de cordeiros deslanados terminados em confinamento com diferentes dietas. Revista Brasileira de Zootecnia 39:363-371.

Berg, R. T. and Butterfield, R. M. 1966. Muscle: bone ratio and fat percentage as measures of beef carcass composition. Animal Production 8:1-11.

Boucinhas, C. C.; Siqueira, E. R. and Maestá, S. A. 2006. Dinâmica do peso e da condição corporal e eficiência reprodutiva de ovelhas da raça Santa Inês e mestiças Santa Inês-Suffolk submetidas a dois sistemas de alimentação em intervalos entre partos de 8 meses. Ciência Rural 36:904-909.

Brasil. Ministério da Agricultura. Secretaria de Inspeção de Produtos Animal - SIPA. 1990. Portaria $\mathrm{n}^{0}$ 307, de 26 dez. 1990. Aprova o Sistema Nacional de Tipificação de Carcaças Ovinas. Diário Oficial da União, Brasília, 27 dez. 1990.

Colomer-Rocher, F. 1984. Metodología de clasificación de canales ovinas. Oleaginosas Españolas S.A., Madrid, Spain.

European Union. 1994. Reglamento (CEE) no 1278/94 del Consejo, de 30 de mayo de 1994, por el que se modifica el Reglamento (CEE) no 2137/92 del Consejo, relativo al modelo comunitario de clasificación de canales de ovino (Council Regulation No. 1278/ 94 of 30 May 1994 modifying Council Regulation No 2137/92, determining the Community scale for the classification of ovine carcasses). D.O.C.E. no L 140, de 3.6.94, p.5.

Garcia, I. F. F.; Costa, T. I. R.; Almeida, A. K.; Pereira, I. G.; Alvarenga, F. A. P. and Lima, N. L. L. 2010. Performance and carcass characteristics of Santa Inês pure lambs and crosses with Dorper e Texel at different management systems. Revista Brasileira de Zootecnia 39:1313-1321.

Hammond, J. 1965. Farm animal: their growths breeding and inheritance. E. Arnould, London. 322p.

Huidobro, F. R.; Miguel, E.; Díaz, M. T.; Velasco, S.; Lauzurica, S.; Pérez, C.; Onega, E.; Blázquez, B. and Cañeque, V. 2004. Carcass classification in suckling lambs. II. Comparison among subjective carcass classification methods: fatness scales and conformation scales with 0.25 point-intervals. Meat Science $66: 135-142$

Johansen, J.; Aastveit, A.H.; Egelandsdal, B.; Kvaal, K. and Røe, M. 2006. Validation of the EUROP system for lamb classification in Norway; repeatability and accuracy of visual assessment and prediction of lamb carcass composition. Meat Science 74:497-509.

Medeiros, G. R.; Costa, R. G.; Andrade, M. G. L. P.; Azevedo, P. S.; Medeiros, A. N.; Pinto, T. F. and Suassuna, J. M. 2011. Estado de engorduramento da carcaça de ovinos Santa Inês e Morada Nova abatidos com diferentes pesos. Actas Iberoamericanas de Conservación Animal 1:243-246.

Miguel, E.; Onega, E.; Cañeque, V.; Velasco, S.; Díaz, M. T.; Lauzurica, S.; Pérez, C.; Blázquez, B. and Huidobro, F. R. 2003. Carcass classification in suckling lambs. Discrimination ability of the European Union scale. Meat Science 63:107-117.

Miguel, E.; Huidobro, F. R.; Blázquez, B.; Velasco, S.; Lauzurica, S.; Pérez, C. and Cañeque, V. 2007. Live weight effect on the 
prediction of tissue composition in suckling lamb carcasses using the European Union scale. Small Ruminant Research 67:199208.

Pannier, L; Gardner, G. E.; Pearce, K. L.; McDonagh, M.; Ball, A. J.; Jacob, R. H. and Pethick, D. W. 2014. Associations of sire estimated breeding values and objective meat quality measurements with sensory scores in Australian lamb. Meat Science 96:1076-1087.
Russo, C.; Preziuso, G. and Verità, P. 2003. EU carcass classification system: carcass and meat quality in light lambs. Meat Science 64:411-416

Souza, D. A.; Selaive-Villarroel, A. B.; Pereira, E. S.; Silva, E. M. C. and Oliveira, R. L 2016. Effect of the Dorper breed on the performance, carcass and meat traits of lambs bred from Santa Inês sheep. Small Ruminant Research 145:76-80. 